\title{
Role of English in Chinese Popular Culture
}

\author{
YE Xiao-ya \\ School of English and International Studies, Beijing Foreign Studies University, Beijing, China
}

\begin{abstract}
Nowadays Chinese have become much more open and willing to welcome and embrace Western culture, and therefore English plays an important role in Chinese pop culture. This paper intends to analyze the role of English in Chinese advertisements, movies and TV shows, which are shown in Mainland China, Taiwan, and Hong Kong. Findings show that English is pervasively used in Chinese commercials in both Mainland China and Taiwan. Unlike the situations in Taiwan, English is always used in combination with Chinese subtitles in Mainland China, most international commercials are re-produced to be more applicable to local Chinese communities, and the strategy of advertising is different. In Hong Kong movies, Hong Kong English is used frequently, which gives the evidence that the language mixing behavior is popular in Hong Kong.
\end{abstract}

Keywords: role of English, Chinese pop culture, advertisements, movies, TV shows

Following World War II, the United States ascended to the lead role on the world's stage through technological advancements, widespread political power, and domination in the world economy. The result was that the mass media of other countries (including film, television, advertising, commercials) provided a medium for spreading the high prestige of Americanness and resulted in the gradual commodification of anything American and desire for all products and practices associated with American culture (Kachru, 1992, p. 215). On the contrary, Mainland China has had a long historical tradition of rejecting outside influence up until the 17th century. Mainland China maintained an inward-focused mentality during that time, in which the Chinese were overtly uninterested in what English had to offer them.

With the end of the Cultural Revolution, economic development became the emphasis, while the class struggle that had previously characterized the social, political, and economic spheres gradually faded away (Latham, 2007, p. 14). The economic reform of the post-Cultural Revolution brought increased wealth and a higher standard of living to China as a whole. Economic reform also encouraged greater individual and family independence and has "fostered new forms of consumerism, individualism, and independence completely unimaginable just thirty years ago, even with the highly personal areas of people’s lives still regulated by the state, such as family planning with the one-child policy” (Latham, 2007, p. 15). Since the Cultural Revolution, a counter-movement has developed in which China is eager to learn foreign ways. The result is that the Chinese have become much more open and willing to welcome and embrace the commodified Western culture that has accompanied globalization and the spread of English, while still maintaining the importance of more traditional aspects of their culture and identity. However, this has created some conflict between these two very different

YE Xiao-ya, Ph.D., School of English and International Studies, Beijing Foreign Studies University, Beijing, China. Research fields: applied linguistics, general linguistics. 
belief systems, as the elder generations are far less willing to accept the pervasive influence of Western values, language, and culture. This situation is accurately described by Kachru who writes, "A complex pattern of acceptance and rejection exists in the target cultures, with the forces of tradition battling the magnetism of change" (Kachru, 1992, p. 217).

As a result of this historical background, the use of English in China demonstrates the sociopolitical situation there (Kachru, 1992, p. 163), particularly in the case of popular culture. Popular culture is a reflection of social and cultural values, desires, and expectations, which is why the use of English in the context of popular culture is so illuminating. Furthermore, the main purpose for the study of English in China is now to gain access to Western science and technology. According to Kachru, "the increased flow of Western tourists and businessmen to China has also made it crucial to use English, though in restricted contexts” (Kachru, 1992, p. 162). Consequently, business, science, and technology are all reasons for the spread of English into a variety of domains in China. Another reason is the increased power and influence of the younger generation of Chinese, or Generation-X, as they have accepted the permeation of English and Western culture and created a demand for its use.

While the mass market in China is very diverse, the younger generation is quickly becoming a driving force in the spread of English and Western culture. The younger generation of Chinese have only ever known the relatively liberal attitudes of the economic reform period. They have grown up surrounded by an ever-expanding and advancing range of media and technology and have been far-removed from the censorship and limited access to information of the Cultural Revolution. According to official Chinese statistics, "approximately 80 percent of China's Internet users are under the age of thirty-five and the majority of these are under thirty" (Latham, 2007, pp. 26-27). As a result, there is a clear divide in the older and younger generations' conception of technology.

While the older generations remain conservative and cling to the preservation of traditional Chinese culture, the younger generation seems quite willing to embrace the increasing influence of English and Western culture. Perhaps this is largely due to the unique social condition of the younger generation which has contributed to their enthusiastic consumption of Western culture and English use. As a result of the one child per family policy, family members have only one child upon which to focus all of their attention, and therefore, this child becomes the center-getting more toys, presents, fast food, and television (Latham, 2007, p. 27). This has encouraged these young people to be particularly in touch with prestigious consumption patterns, which generally involves a strong connection with Western culture and products. As a result of this unique situation, the advertising industry has exploited the heightened susceptibility to the ebb and flow of consumer culture of these young people.

Chinese multinational companies have targeted the young adults of this X-Generation with their advertising and marketed their brands toward them by accentuating Western values in their advertising (ZHANG \& Shavitt, 2003, pp. 21-22). According to a study of consumer profiles of eight toothpaste brands in China, there is evidence that “multinational companies' advertising values were reflected in their brand users' profiles” (ZHANG \& Shavitt, 2003, p. 22). The results of this study showed that the users of Crest toothpaste are typically younger and wealthier than those of domestic brands such as Blue Sky. Crest users were also found to be more open to different values, less traditional than the users of domestic brands, more responsive to advertising, and more likely to embrace the Western values of individualism and freedom (ZHANG \& Shavitt, 2003, p. 22).

The findings of this study provide concrete evidence for the pervasive influence of Western culture and language on the consumption patterns of young Chinese. Consequently, it is not surprising that English pervades 
Chinese advertisements to the extent that it does. The X-Generation has tremendous buying power, and is very closely in touch with the most up-to-date media and technology, which makes them more receptive to commercials and thus perfect receptacles/targets for advertisers. Consequently, these advertisers have successfully tapped into the perceptions and stereotypes associated with English use and Western culture, such as sophistication, future, innovation, and competence. Advertisers rely on such associations to grab the attention of young Chinese consumers, and influence their buying power.

\section{Analyses of Advertisements in Mainland China}

The main socio-psychological features that English has acquired in global advertising are listed vividly in Table 1:

Table 1

English: Socio-psychological Features (Bhatia \& Ritchie, 2008, p. 537)

\begin{tabular}{|l|l|}
\hline Threshold trigger & Proximity zones \\
\hline Future and innovation & vision, foresightedness, advancement, betterment \\
\hline American or English culture & limited Westernization, Christianity, values such as independence, freedom, modernization \\
\hline Internationalism and standardization & certification, standards of measure, authenticity \\
\hline Rationality and objectivity & scientific appeal, problem solving \\
\hline Competence & efficiency, organization, quality, safety, protection, functionality, pragmatism \\
\hline Sophistication & elegance, style, rarity \\
\hline Physical fitness & self-improvement \\
\hline
\end{tabular}

Based on the above chart, the analyses of some advertisements in Mainland China are elaborated in the following.

1. VISA commercial for 2008 Olympic Games (http://www.youtube.com/watch?v=xzZjeAK3r8Q)

In this commercial, English is used mainly in two ways: (1) the lyrics of the background music are presented in English; (2) all the words, including both the spoken and the written words, are in English. These words include "visa”, "Beijing 2008 Olympic Games”, “join the team”, “martial arts (magazine’s name)”, “out”, "Easiest way to get to Beijing Olympics”, "Visa. Only Card accepted at the Beijing 2008 Olympic Games”, and "All it takes".

The function of English usage in this advertisement is to emphasize the competence of the Visa Card, including safety/security, protection, efficiency, etc. as well as the Internationalism and standardization of the card, such as the standards of measure and authenticity.

2. Skoda Advertising—Mainland China (http://www.youtube.com/watch?v=hcc9MGH74js)

In this commercial all the written Chinese words, which describe the features of the product, have their English equivalence, including "Intelligence”, "Attractiveness", and "Dedication”. Furthermore, at the end of the commercial, it presents the brand of the car "Skoda Auto" and "Shanghai Volkswagen" in English.

The English employed in this advertisement shows the product with the following qualities: (1) future and innovation: vision, advancement, betterment; (2) competence: quality, efficiency, safety, functionality; and (3) sophistication: elegance, style.

3. Wall’s Cornetto—“Train” (http://www.youtube.com/watch?v=MDoIpwTSHAs) 
In this advertisement the dialogue between the man and the woman is in written language, and presents in both Chinese and English. The English version of the dialogue is:

Man: "Hi."

Woman: "I see you have good taster."

Man: "Really?"

The girl shakes her head, and looks at the product.

Man: "Will I see you again?"

Woman: "What do you think?"

The English written dialogue employed in this commercial aims at showing the product with the features of American Culture as well as sophisticated style.

4. Ad: iPod nano (http://www.youtube.com/watch?v=MOTftr7l_54)

This commercial is mainly composed of an original English song with Chinese subtitle to imply that the product, iPod nano, contains the features of American Culture, i.e. modernization and freedom, high quality, and sophistication such as elegance and style.

5. Duracell World Cup 2006 Mainland China Advertisements

(http://www.youtube.com/watch?v=713DV8iIV-c)

There are many English signs in this advertisement, including "The World Cup Germany 2006”, "Extra time”, "Duracell competitive Testing 2005" and "Extra Power". English signs used in this commercial mainly demonstrate the competence of the battery including its efficiency, quality, durability, functionality, as well as pragmatism.

6. VO5 China Ad (http://www.youtube.com/watch?v=WGoLgIClXtc)

To fully understand this commercial, we need some cultural and historical knowledge about Mainland China in the 1970s. At that time, teenagers at school were strictly forbidden to look at as well as talk to their classmates with opposite gender. In this advertisement the boy and the girl broke the rule and looked at each other to show their appreciation, however the teacher spoke in Chinese repeatedly: “Don’t look at each other” (This English sentence is the translated version). The boy and the girl promoted their rebellion to the climax by using VO 5 gel to change their hairstyle. The English sentence was spoken as well as written at the end of the commercial "VO 5 Extreme Style. Break the mould."

The English used in this advertising aims at presenting VO 5 gel with the feature of American culture, i.e. independence and freedom, as well as the quality of sophistication, namely style and rarity.

\section{Analyses of Commercials in Taiwan}

Table 2

Commercials in Taiwan

\begin{tabular}{|l|l|l|}
\hline Commercial title & Data & Threshold trigger \\
\hline Tourism Commercial & http://tw.youtube.com/watch?v=geeREH9pkYQ & Internationalism \\
\hline VIVA Nuts Commercial & http://www.youtube.com/watch?v=RH15o7XExAM & $\begin{array}{l}\text { Attention getting: making fun of their } \\
\text { Taiwanese accent to entertain the audience }\end{array}$ \\
\hline $\begin{array}{l}\text { Hess Educational } \\
\text { Organization }\end{array}$ & $\begin{array}{l}\text { http://tw.youtube.com/watch?v=T_UbhyuPJsw } \\
\text { http://tw.youtube.com/watch?v=tAaeUsD0-vY } \\
\text { http://tw.youtube.com/watch?v=3yIsmWFUJK0 }\end{array}$ & $\begin{array}{l}\text { No Chinese subtitles: attention getting, future } \\
\text { \& innovation, advancement, competence }\end{array}$ \\
\hline English Magazines & http://tw.youtube.com/watch?v=mx0mPtfqBwk & Taiwanese accent: attention getting \\
\hline
\end{tabular}


The use of English in commercials played in Taiwan has been really popular for the past decades. In advertisements, there are many strategies for using English, the first foreign language in Taiwan. The first video clip in the above chart is a commercial for tourism, in which the government intends to introduce Taiwan to the world; the clip is set to speak in English for the reason that English is viewed as a global language. Being a global language, English in advertisements sometimes has other purposes rather than being that formal and serious. The second video clip can be one of the examples: English is spoken with a Taiwanese accent for an entertaining reason. Since English is regarded as the most important foreign language in Taiwan, people there are not just always envious of someone who has perfect English accent, but also mock at someone who has funny Taiwanese accent. That is the reason for that people get attracted by this commercial at that time (This commercial was one of the most famous commercials in Taiwan). Therefore the use of English functions as attention getting, one of the required elements in successful advertisements.

Because of the importance of English, bilingual education is deemed as the best education for children nowadays. Therefore, English training programs have been received numerous popularities in Taiwan. Children in Taiwan are forced to attend night schools for extra English courses to get future competence. The aggressive attitudes can be found in the commercials of these English programs. The interesting point in their commercials is that there is no Chinese subtitle, which also functions as attention getting. Moreover, many other commercials are being played without Chinese subtitles as well. The links below of many successful advertisements lend support to the claim that people in Taiwan really welcome English language in their daily life, and they are even more attracted by commercials in English only rather than in pure Chinese.

Table 3

Pure English Usage in Commercials in Taiwan

\begin{tabular}{|l|l|l|}
\hline Products & Data & Threshold trigger \\
\hline Samsung Cell Phone & http://tw.youtube.com/watch?v=fS5983XxKoc & $\begin{array}{l}\text { Future \& Innovation, Advancement, } \\
\text { Competence }\end{array}$ \\
\hline CK Fragrance & http://tw.youtube.com/watch?v=Yesf2gUViHc & Sophistication \\
\hline iPod & http://tw.youtube.com/watch?v=7FR7ZhRo1eM & $\begin{array}{l}\text { Future \& Innovation, Advancement, } \\
\text { Competence, and American Culture }\end{array}$ \\
\hline
\end{tabular}

The types of products using English only in their commercials as a strategy include items of technology, fashion business, fine art, and International companies like NIKE, Microsoft, and McDonald's. This phenomenon not only explains a result from globalization, but also strongly suggests that English language is indeed accepted by people in Taiwan.

\section{Contrast Between Advertisements in Mainland China and in Taiwan}

Advertisements in Mainalnd China and the ones in Taiwan have significant differences. Table 4 shows the different characteristics. 
Table 4

Differences Between Advertisements in Mainland China and in Taiwan

\begin{tabular}{|l|l|}
\hline Mainland China & Taiwan \\
\hline English is always used in combination with Chinese subtitles. & Only English is used in many commercials. \\
\hline $\begin{array}{l}\text { Most international commercials are re-produced to be more } \\
\text { applicable to local Chinese communities. }\end{array}$ & $\begin{array}{l}\text { Many original international commercials are shown in Taiwan. } \\
\text { Some of them are even without any Chinese subtitles. }\end{array}$ \\
\hline $\begin{array}{l}\text { Because of the history and the current political situation, people } \\
\text { in Mainland China have less access to American culture than } \\
\text { people in Taiwan do. They also accept English less than people } \\
\text { in Taiwan do. As a result, the strategy of advertising would be } \\
\text { different from that in Taiwan. }\end{array}$ & $\begin{array}{l}\text { leople in Taiwan have more access to American culture due to } \\
\text { mass media, so they accept it more easily than people in } \\
\text { Mainland China do. They consider American culture to be } \\
\text { modern and trendy, and therefore they welcome it. On the } \\
\text { contrast, mainland Chinese often see it as interfering with } \\
\text { Chinese culture, so they try to keep its influence limited. }\end{array}$ \\
\hline
\end{tabular}

\section{Analyses of Movies and TV Shows}

Movies depict the real sub-culture existing in a society, and the language use in the script therefore reflects the true linguistic phenomenon underlyingly applied in the area. Hong Kong entertainment industry is famous for its movie productions, and it is also the most productive movies makers in East Asia. Due to being a colonized area by British government for several decades, Hong Kong has marked language mixing features among Mainland China, Taiwan, and other Chinese-speaker-dominated areas. Many previous research studies discussed this chaos of language mixing use in Hong Kong in order to purify the use of Chinese and English respectively. Still, this mixing behavior is increasingly happening not only between Mandarin and English, but also between Cantonese and English as the linguistic fact is that most people in Hong Kong write Chinese characters, but speak Cantonese, so that the language mixing behavior is even more complicated. In Hong Kong movies, Hong Kong English can be found everywhere, which gives the evidence that the language mixing behavior is really popular in Hong Kong.

Table 5

Language Mixing Behavior in Hong Kong

\begin{tabular}{|l|l|l|}
\hline Hong Kong English & Inner-circle English & Traditional Chinese and its meaning \\
\hline Bye-bye & Bye bye & Manzou (walk slowly) \\
\hline Ah sir & Sir & Minjing (servant fellow) \\
\hline Desi & Texi & Chuzuche (rent car) \\
\hline Shido & Store & Shangdian \\
\hline Dina & Dinner & Wancan \\
\hline
\end{tabular}

These words have been used to replace Chinese words in the daily conversations of Hong Kong people, and these words are generally used in Hong Kong movies as well. Some video clips from Hong Kong movies, which are listed in the following, interestingly support the claim above:

Data Retrieved from

http://tw.youtube.com/watch?v=dBpaKp9Ucj8

http://tw.youtube.com/watch?v=liXPRuU4Bt0

TV shows is also a domain which pictures how a society deals with a non-native language. One of the top TV shows in Taiwan uses an English game as the show's main topic. The rule of the game in this show is to guess English words based on a person's gestures and verbal hints. This game underlyingly assumes that basic-level English vocabulary has become common knowledge for people in Taiwan in their daily conversation. Therefore it gives support that English is regarded as a required skill in Taiwan. 
Data Retrieved from

http://tw.youtube.com/watch?v=W3OIzMYe1mI

http://tw.youtube.com/watch?v=bo432hX3D_o\&feature=related

\section{Conclusion}

The pervasive influence of English on Chinese popular culture is undeniable. It has infiltrated the domains of advertising, television, and movies, to name a few. This sweeping penetration has been largely instigated by advertisers exploiting associations and stereotypes of Western culture and products, as well as by the current social and political environments. This extensive influence has had a profound effect on Chinese culture. Advertising has promoted individualistic and modern values, and also reflected China's cultural values and orientation, since media promoting individualism and freedom are targeted at the younger generations, while media advocating collectivism are typically targeted at the older generations. While English use is extensive and widespread in Mainland China, the level of acceptance of English largely depends on age. Although English has been widely accepted and embraced by the younger generation, the older generation maintains reservations, as they are worried that the increased exposure to Western culture will usurp their own highly valued Chinese traditions and culture. Unlike in the past, advertising in Mainland China is now promoting more individualistic values to the younger generation. However, there still remains a distinction between the attitudes of Mainland China and Taiwan towards Western influence. Due to Taiwan's history as a trade center, it received a greater flow of ideas than Mainland China. Consequently, Mainland China and Taiwan employ English in different ways and for different purposes: as for advertisements shown in Mainland China, English is always used in combination with Chinese subtitles, most international commercials are re-produced to be more applicable to local Chinese communities, and the strategy of advertising is different from that in Taiwan.

\section{References}

Bhatia, T. K., \& Ritchie, W. C. (2008). Bilingualism in the global media and advertising. In T. K. Bhatia and W. C. Ritchie (Eds.), The handbook of bilingualism. New York, NY: Wiley-Blackwell.

Kachru, B. B. (1992). The other tongue: English across cultures (2nd ed). Chicago: University of Illinois Press.

Latham, K. (2007). Pop culture China!: Media, arts, and lifestyle. Santa Barbara, CA: ABC-CLIO.

ZHANG, J., \& Shavitt, S. (2003). Cultural values in advertisements to the Chinese X-Generation: Promoting modernity and individualism. Journal of Advertising, 32(1), 23-33. 